\title{
An antagonist of the retinoid $X$ receptor reduces the viability of Trichuris muris in vitro
}

\author{
Rebecca JM Hurst ${ }^{1 *}$, Thomas Hopwood ${ }^{1}$, Amanda L Gallagher ${ }^{1}$, Frederick A Partridge ${ }^{1,2}$, Timothy Burgis ${ }^{1}$, \\ David B Sattelle $e^{1,2}$ and Kathryn J Else ${ }^{1}$
}

\begin{abstract}
Background: Trichuriasis is a parasitic disease caused by the human whipworm, Trichuris trichiura. It affects millions worldwide, particularly in the tropics. This nematode parasite burrows into the colonic epithelium resulting in inflammation and morbidity, especially in children. Current treatment relies mainly on general anthelmintics such as mebendazole but resistance to these drugs is increasingly problematic. Therefore, new treatments are urgently required.
\end{abstract}

Methods: The prospect of using the retinoid X receptor (RXR) antagonist HX531 as a novel anthelmintic was investigated by carrying out multiple viability assays with the mouse whipworm Trichuris muris.

Results: HX531 reduced both the motility and viability of T. muris at its $L 3, L 4$ and adult stages. Further, bioinformatic analyses show that the T. muris genome possesses an RXR-like receptor, a possible target for HX531.

Conclusions: The study suggested that Trichuris-specific RXR antagonists may be a source of much-needed novel anthelmintic candidates for the treatment of trichuriasis. The identification of an RXR-like sequence in the T. muris genome also paves the way for further research based on this new anthelmintic lead compound.

Keywords: RXR, HX531, Trichuris muris, Nematode, Viability, Anthelmintic

\section{Background}

Trichuris trichiura, the human whipworm, is an intestinal nematode affecting over 450 million people worldwide, particularly those living in the tropics [1]. T. trichiura burrows into the epithelial lining of the colon to cause inflammation, and in cases of high parasite burden can lead to diarrhoea, poor growth, finger clubbing, anaemia and rectal prolapse [2]. Other members of the Trichuris genus can have damaging effects on livestock, decreasing productivity and thus causing farming communities to be trapped in a state of poverty. Currently, the only treatment for trichuriasis is the distribution of anthelmintics, such as mebendazole. However, these drugs only affect the adult stage of the parasite, and resistance is becoming increasingly common; in some cases mebendazole has been reported to be as low as $45 \%$ effective [3]. Even when parasites are cleared from the

\footnotetext{
* Correspondence: rebecca.hurst@manchester.ac.uk

${ }^{1}$ Faculty of Life Sciences, University of Manchester, AV Hill Building, Oxford Road, Manchester M13 9PT, UK

Full list of author information is available at the end of the article
}

host, re-infection from the environment is common. Therefore, there is an urgent medical need for new treatments for this parasitic infection.

Nuclear hormone receptors such as the retinoid X receptor (RXR) play many vital roles in the development of organisms [4]. Indeed, RXR $\alpha \mathrm{KO}$ mice are not viable [5]. In mammals, there are three isoforms of intracellular RXR receptors ( $\alpha, \beta$ and $\gamma$ ), and these function as heteroor homo-dimers [6]. Upon dimerisation, co-activator or co-repressor molecules are recruited and the transcription of genes under the control of these receptors is modified. The natural ligand for RXR homodimers is 9-cis-retinoic acid, however, since RXR can heterodimerise with other nuclear hormone receptors such as the retinoic acid receptor (RAR), peroxisome proliferator-activated receptor (PPAR) and vitamin D receptor (VDR), its ligands also include all-trans-retinoic acid, fatty acids and vitamin D $[7,8]$.

Since RXR receptors are highly evolutionarily conserved [9], it is not unreasonable to propose that parasites may also have similar receptors. Indeed, the parasitic trematode 
Schistosoma mansoni has been shown to possess RXR-like receptors [10]. In this parasite, a role for such receptors in the expression of female genes has been proposed [10]. Retinoic acid may have several important functions in parasites. For example, Onchocerca volvulus secretes a protein which sequesters retinoic acid [11]. Also, the Ascaris suum ABA-1 allergen has demonstrated retinol and retinoic acid binding capabilities [12] and Brugia malayi has been shown to take up radio-labelled retinoic acid [13]. Retinoic acid is a ligand of RXR, therefore this may suggest important roles of RXR in parasitic species. This study tested whether RXR is important in the biology of Trichuris muris, the laboratory model parasite for human trichuriasis, by investigating the actions of an RXR-active compound on T. muris viability. T. muris is maintained in laboratory mice by oral infection of embryonated eggs. Eggs hatch in the large intestine and progress through four larval stages before becoming fecund adults at around day 35 postinfection [14].

Bioinformatic analysis of the T. muris genome [15] demonstrated that $T$. muris possesses an RXR-like receptor. Two synthetic retinoids known to modulate the function of mammalian RXR were used to target worm viability in vitro. HX630 is an RXR agonist which can bind to RXR and also to nuclear hormone heterodimers, which include RXR as a partner, thereby activating RXR signalling, including RXR-RAR signalling [16,17]. Conversely, HX531 is an antagonist of RXR and has been shown to inhibit both RXR-RAR heterodimers and PPAR $\gamma$-RXR heterodimers in mammalian cells $[18,19]$. To our knowledge, neither HX630 nor HX531 have been tested for anti-parasitic activity. The blocking of the RXR receptor by HX531 reported here results in reduced viability of the $T$. muris parasite at L3, L4 and adult stages of its lifecycle. Three different assays were used to assess worm viability (motility scoring, MTT assay and a novel camera-based method) and their utility as a measure of worm health was compared. The findings suggest that RXR may represent a much-needed, novel drug target for the treatment of trichuriasis.

\section{Methods}

\section{Animals, parasites and compounds}

Immunodeficient SCID mice were bred by the Biological Services Facility (BSF, University of Manchester, UK). All procedures carried out on animals were performed under a Home Office licence approved by the University of Manchester Ethical Review body, and complied, at all times, with UK laws and regulations. Mice were housed in sterile conditions and all experiments were carried out in accordance with the UK Animals (Scientific Procedures) Act 1986.

The T. muris (Edinburgh (E) strain) was maintained as previously described by Wakelin [20]. For in vitro assays,
SCID mice were infected with approximately 200 infective T. muris eggs by oral gavage. At days 24, 31 and 40, mice were sacrificed and the caecum and colon were removed, opened longitudinally and washed in prewarmed $0.9 \% \mathrm{NaCl}$. Guts were incubated in $0.9 \% \mathrm{NaCl}$ at $37^{\circ} \mathrm{C}$ for $1 \mathrm{~h}$. Parasites were isolated and 4 parasites per well were transferred into a 96-well plate containing $100 \mu \mathrm{l}$ fresh RPMI 1640 medium supplemented with penicillin $(500 \mathrm{U} / \mathrm{ml})$ and streptomycin $(500 \mu \mathrm{g} / \mathrm{ml})$. Compounds of interest were added to make a final volume of $200 \mu \mathrm{l}$ per well. Final concentrations of the compounds were as follows: Mebendazole (Ovex) (McNeil, Berkshire, UK) 200, 100 and $50 \mu \mathrm{g} / \mathrm{ml}$; HX630 (RXR Agonist) and HX531 (RXR Antagonist) (both kind gifts from Hiroykui Kagechika, Tokyo Medical and Dental University, Japan) 100, 10 and $1 \mu \mathrm{M}$. HX630 and HX531 were dissolved in $0.2 \%$ DMSO, and therefore the vehicle treatment consisted of $0.2 \%$ DMSO without any active drug. Bleach (5\%) was used as a positive control. Negative control wells contained $200 \mu \mathrm{l}$ RPMI 1640 media plus penicillin $(500 \mathrm{U} / \mathrm{ml})$ and streptomycin $(500 \mu \mathrm{g} / \mathrm{ml})$.

\section{Motility assay}

Following incubation with test compounds for $24 \mathrm{~h}$, the motility of T. muris larvae was assessed using an Olympus SD-ILK microscope. A scale of $0-3$ was used; $0=$ dead, $1=$ very low motility, $2=$ low motility and $3=$ normal motility [21].

\section{MTT assay}

After $24 \mathrm{~h}$ incubation with the test compounds, worms were transferred into $100 \mu \mathrm{l}$ fresh RPMI 1640 medium plus penicillin $(500 \mathrm{U} / \mathrm{ml})$ and streptomycin $(500 \mu \mathrm{g} / \mathrm{ml})$. $100 \mu \mathrm{l}$ MTT reagent (Thiazolyl blue tetrazolium bromide; Sigma, Dorset, UK) was added to each well at a concentration of $6 \mathrm{mg} / \mathrm{ml}$ in deionised water. The plate was then incubated at $37^{\circ} \mathrm{C}, 5 \% \mathrm{CO}_{2}$ for $1 \mathrm{~h}$. The larvae were transferred into a new 96 well plate containing $200 \mu \mathrm{l}$ DMSO and again incubated at $37^{\circ} \mathrm{C}, 5 \% \mathrm{CO}_{2}$ for $1 \mathrm{~h}$ to solubilise the formazan crystals. The worms were removed and absorbance of formazan was measured at a wavelength of $490 \mathrm{~nm}$ using a microplate reader (Dynex Technologies, VA, USA).

\section{Camera motility assay}

Parasites were filmed recorded in 96 well plates for 200 frames at 10 frames per second using an Andor Neo camera and LED array illumination. Parasite motility was determined by an algorithm that thresholds the movie based on variance in pixel intensity over time and then counts motile pixels. 


\section{Bioinformatics}

Protein sequences from the T. muris gene set 2.1 (Feb 2013) were obtained from ftp.sanger.ac.uk/pub/pathogens/ Trichuris/muris/ and used to build a local BLAST database. The human RXR alpha protein sequence was queried against this database using blastp 2.2.29+. The most significant four matches were aligned, using Clustal Omega, against representatives of the RXR gene family and the related NR2F gene family, and selected nematode genes annotated as RXR homologues. The more distantly related C. elegans protein NHR-49 was used as an out group. A phylogenetic tree was constructed using the neighbourjoining method.

\section{Statistics}

Statistical analyses were performed using the unpaired t-test or one way ANOVA (with Tukey's multiple comparison post-hoc test), as appropriate, with the statistical package GraphPad Prism (Version 6). A p value of less than 0.05 was considered significant.

\section{Results}

The $T$. muris genome contains an RXRa-like sequence

Given the availability of the T. muris genome, the conserved nature of the RXR nuclear hormone receptor and the knowledge that other parasitic nematodes have retinoic acid binding capacity, the human RXR $\alpha$ protein sequence was queried against the T. muris gene set 2.1 (Feb 2013). The most significant four matches were aligned against representatives of the RXR gene family, including genes from other nematodes annotated as RXR homologues [22], and representatives of the related NR2F gene family. The more distantly related C. elegans protein NHR-49 was used as an outgroup. Figure $1 \mathrm{~A}$ is a neighbour joining tree showing the relationship between these sequences. T. muris appears to have a single orthologue of the RXR genes [TMUE:s0189001000], which encodes a protein that is $55 \%$ identical to human RXR $\alpha$.

To support the hypothesis that this gene encodes a functional receptor, sequence conservation was analysed more closely. Key residues in the DNA-binding domain, including both zinc fingers and the P-box and T-box sequences [23] are conserved between human RXR and T. muris sequences (Figure 1B). Residues in the ligandbinding domain known to be important for functionality of nuclear hormone receptors [24] are also conserved (Figure 1C). Whilst this does not demonstrate that T. muris TMUE_s0189001000 acts functionally as a retinoid $\mathrm{X}$ receptor, is does suggest that it is a functional nuclear hormone receptor and is closely related to the RXR family. Furthermore, homologues of this receptor are found in other parasitic nematodes (Figure 1A), suggesting RXR-active compounds have the potential to interfere with parasite biology.
The RXR antagonist HX531 reduced the viability of L3/L4 T. muris in vitro

To assess whether the RXR antagonist HX531 affects the viability of the L3 and L4 stages of the T. muris parasite, larvae were extracted from infected mice at day 24 post infection, a time point when both L3 and early-moulted L4 larvae are present. Larvae were incubated with HX531 at concentrations of 100,10 and $1 \mu \mathrm{M}$ for $24 \mathrm{~h}$. As controls, parasites were also incubated with the anthelmintic mebendazole (200, 100 and $50 \mu \mathrm{g} / \mathrm{ml}$ ), RXR agonist (HX630; 100, 10 and $1 \mu \mathrm{M}$ ), vehicle, media only or bleach (1:100). When incubated with mebendazole $(200 \mu \mathrm{g} / \mathrm{ml})$ or bleach, both larval stages had a significantly reduced motility score compared to media-only controls $(p<0.01$ and $p<0.001$, respectively) (Figure 2A). Interestingly, HX531 $(100 \mu \mathrm{M})$-treated larvae also had a significantly reduced motility score compared to vehicle treatment $(p<0.001)$ (Figure 2A), as well as reduced viability shown by the MTT assay data $(p<0.05)$ (Figure $2 \mathrm{~B}$ ). Worm motility was also assessed using a camera which tracked the movement of the worm followed by measuring changing pixels in a frame-by-frame analysis. Using this assay, L3-L4 T. muris larvae incubated with mebendazole $(200 \mu \mathrm{g} / \mathrm{ml})$ or bleach again had significantly reduced motility compared to media-only controls ( $p<0.001$ for both) (Figure 2C and D). However, both the RXR antagonist $(100 \mu \mathrm{M})$-treated larvae and RXR agonist $(100 \mu \mathrm{M})$-treated larvae showed a significantly reduced motility compared to vehicle treatment ( $p<0.05$ for both) (Figure 2C and D).

\section{The RXR antagonist HX531 reduced the viability of L4 and} adult $T$. muris, in vitro

L4-adult $T$. muris were recovered at day 31 post-infection, a time point when both newly moulted adults are present but some worms still remain as L4. Incubation with bleach significantly reduced motility scores compared to mediaonly controls ( $\mathrm{p}<0.01$ for both) (Figure 3A). Again, RXR antagonist treatment $(100 \mu \mathrm{M})$ resulted in significantly reduced motility scores compared to vehicle controls $(p<0.001)$ (Figure 3A). Using the motility score assay, neither mebendazole nor the RXR agonist had any effect on parasite viability (Figure 3A). MTT assay data showed that RXR antagonist treatment at both $100 \mu \mathrm{M}$ and $10 \mu \mathrm{M}$ significantly reduced viability compared to vehicle-treated controls ( $p<0.05$ for both) (Figure 3B). None of the other treatments had any significant effect on parasite viability compared to controls in the MTT assay (Figure 3B). Camera analysis of worm movement showed a reduced motility in parasites incubated with bleach, compared to media only controls $(p<0.001$ for all) (Figure $3 \mathrm{C}$ and $\mathrm{D}$ ). RXR antagonist treatment also caused a significant reduction in movement compared to vehicle controls at all three concentrations tested (100, 10 and $1 \mu \mathrm{M})(\mathrm{p}<0.001$ for all) (Figure $3 \mathrm{C}$ and D). 
Mebendazole and RXR agonist-treatment had no significant effect on worm motility using this analysis (Figure 3C and D).

The RXR antagonist HX531 reduced the viability of adult T. muris, in vitro

To confirm the effects of RXR compounds on adult T. muris alone, worms were extracted at day 40 post-infection a time at which all worms present are mature adults. The adult parasites had a reduced motility score when incubated with bleach compared to media only controls $(p<0.001)$ (Figure 4A). None of the other treatments had a significant effect on T. muris motility scores (Figure 4A). However, the
MTT assay revealed a decreased parasite viability with RXR antagonist treatment $(100 \mu \mathrm{M})$, as well as the bleach, when compared to vehicle controls $(p<0.05$ for both) (Figure 4B). Mebendazole or RXR agonist treatment showed no significant impact on worm vitality at any of the concentrations tested, using the MTT assay (Figure 4B). However, the camera-based analysis of worm movement showed that mebendazole $(200 \mu \mathrm{g} / \mathrm{ml})$ as well as bleach reduced worm motility compared to media only controls ( $p<0.01$ for both) (Figure $4 \mathrm{C}$ and D). RXR antagonist $(100 \mu \mathrm{M})$ treatment also caused a significant attenuation of worm motility compared to vehicle controls $(p<0.05)$, 


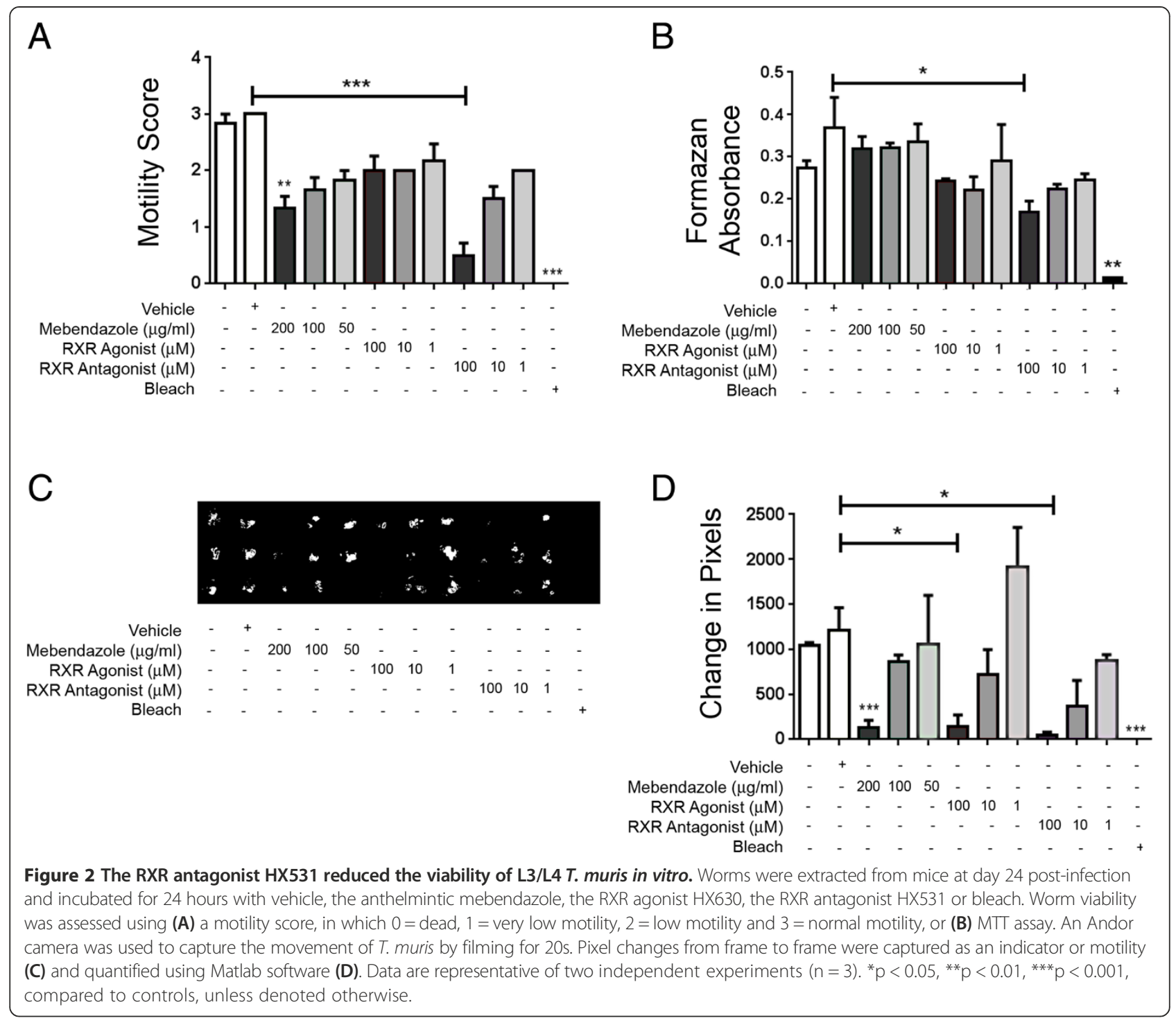

although this was also observed with RXR agonist $(100 \mu \mathrm{M})$ treatment $(\mathrm{p}<0.05)$ (Figure $4 \mathrm{C}$ and $\mathrm{D})$.

Overall, the RXR antagonist HX531 emerges as a candidate lead compound for a novel anthelmintic, acting on both larval and adult stages of the parasite. Its anti-parasitic activity was detected using three different vitality assays for worms recovered at day 21 (L3/L4) and day 31 (L4/adult) and two out of three assays for the day 40 mature adult stage parasites.

\section{Discussion}

Gastrointestinal helminth infections affect over 1 billion people worldwide and are a significant cause of human and livestock morbidity. With resistance to current treatments becoming increasingly problematic and with the lack of any vaccine, novel anthelmintics are urgently required [3]. In this study, it was demonstrated for the first time that RXR antagonists show anthelmintic activity and may therefore serve as important lead compounds in the search for new treatments for nematode infections. At L3, L4 and adult stages of the parasite, the human RXR antagonist HX531 was able to reduce both the motility and viability of $T$. muris larvae in vitro, as determined by a range of viability assays. The RXR agonist HX630 also reduced worm motility in the L3/L4 and mature adult only stages, however this was only observed in one viability assay. Earlier work has demonstrated that synthetic retinoids that are weak RAR agonists are able to interfere with the development of filarial nematodes in vitro $[25,26]$. Our studies of an RXR agonist and antagonist in three different parasite viability assays, show that the RXR antagonist (HX531) displays the most robust anthelmintic properties.

RXR is a nuclear hormone receptor which can heterodimerise with many different partners, such as the vitamin $\mathrm{D}$ receptor (VDR) or retinoic acid receptor (RAR). Owing 


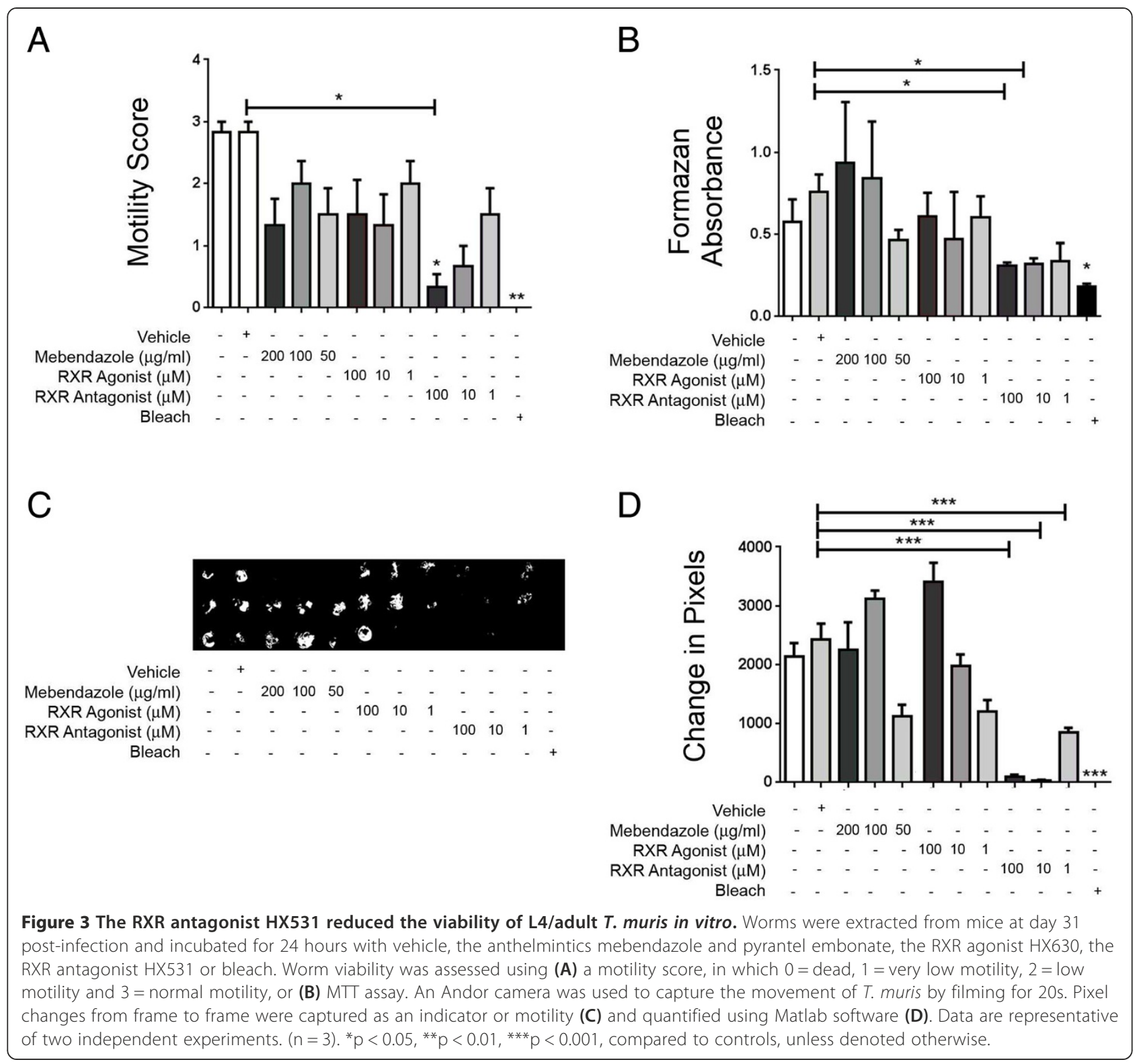

to its promiscuous nature, RXR is responsible for controlling the transcription of a variety of different genes and therefore has a wide range of physiological effects, including those essential for homeostasis and development. For example, the human RXR controls fundamental biological processes from reproduction to embryonic development to cell proliferation $[8,27]$. Thus, it is not surprising that disruption of the RXR signalling pathway could have a detrimental effect on organism viability. An RXR-like receptor has been shown to exist in the trematode parasite Schistosoma mansoni. Studies have shown that the SmRXR is expressed constitutively and therefore may have many roles throughout the parasite's lifecycle [28]. The findings in this investigation are in accord with this, as RXR antagonism was able to reduce $T$. muris viability at three different lifecycle stages; L3, L4 and adults.

The study demonstrated, for the first time, that T. muris has an RXR-like sequence in its genome. This is important not only in terms of novel drug targets, but also in the context of helminth biology. The presence of this receptor indicated that ligands for RXR may be important in Trichuris health. Current understanding of T. muris feeding processes are limited. It is thought that the stichosome gland cells release enzymes which break-down food externally and then nutrients are taken up by bacillary cells $[29,30]$. If RXR is important for T. muris health, these nutrients might include those that act through RXR signalling, such as retinoic acid or vitamin D. 


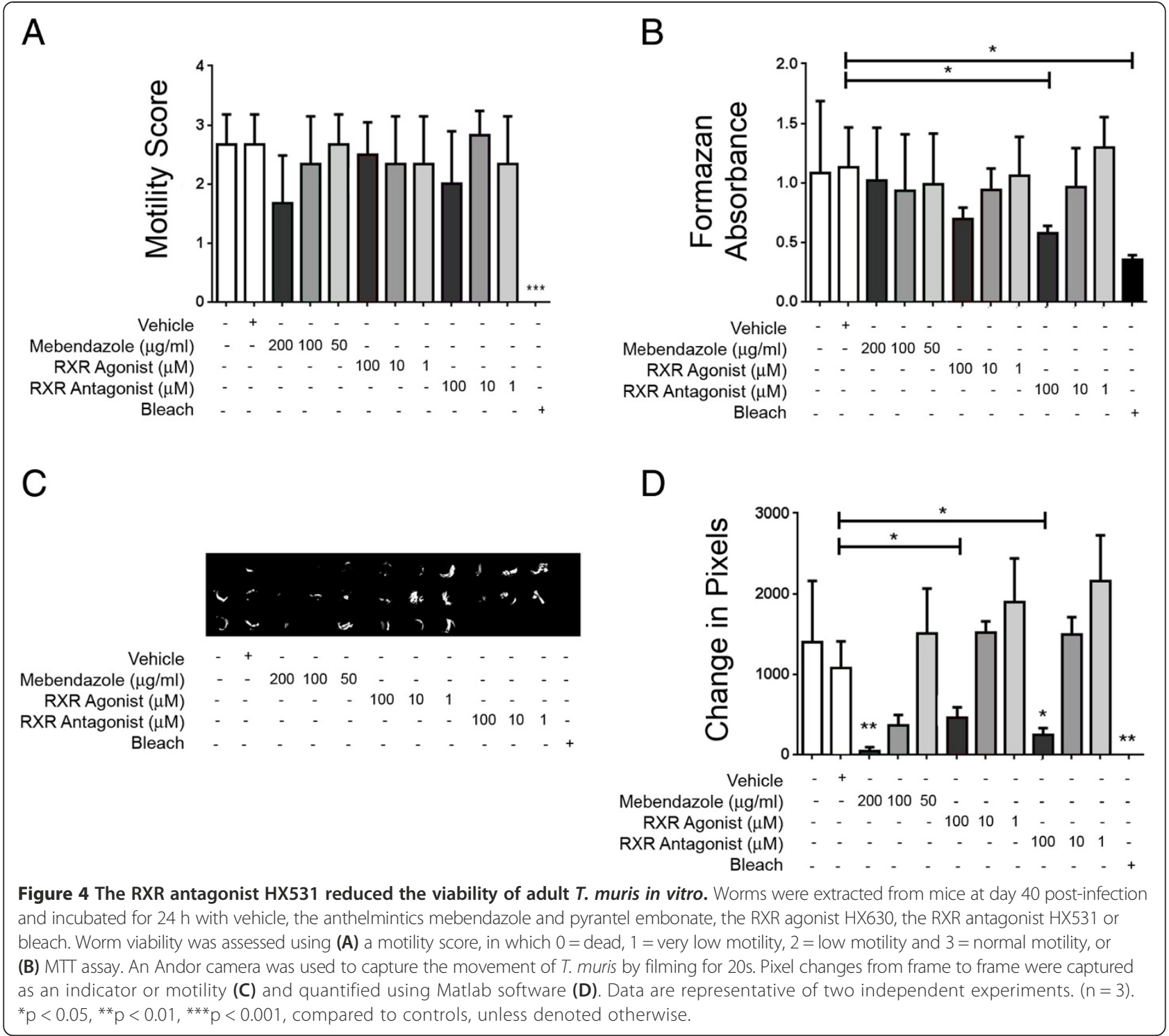

The use of vitamin A to treat nematode infections is controversial. A study has shown that vitamin A supplementation to Ascaris-infected individuals can promote worm-clearing Th2 responses [31]. In contrast, we have previously reported that activation of the vitamin A receptor, RAR, can cause increased inflammation in the host during T. muris infection [32]. Remarkably, vitamin A deficiency is associated with an increased ability to control T. muris infections via innate lymphoid cell type 2 dependent immunity [33]. The data presented in the current paper suggest that exploring the impact of vitamin $\mathrm{A}$ or its metabolite retinoic acid on the nematode itself as well as on its host responses is of considerable interest.

This study showed that the half-maximal inhibitory concentration for HX531 on T. muris viability was between $10 \mu \mathrm{M}$ and $100 \mu \mathrm{M}$. This was higher than $0.29 \mu \mathrm{M}$ - the reported IC50 of HX531 in mammalian kidney cells [34]. This difference in potency may reflect the variations in RXR sequence between mammals and parasites. Bioinformatic analysis of the T. muris genome revealed that this parasite has a sequence with 55\% homology with the human RXR $\alpha$ nuclear hormone receptor. Ideally anti-parasitic drugs should affect the parasite and not the host. For example, mebendazole binds to nematode $\beta$-tubulin to prevent transport of secretory vesicles [35]. However, a current, widely-used anthelmintic, ivermectin, has recently been identified as a novel FXR ligand [36] in additions to its actions on glutamate-gated chloride channels [37]. FXR is a nuclear hormone receptor which heterodimerises with RXR and thus this supports the principle of targeting nuclear hormone receptors in the development of novel anthelmintics. Looking to the future, the development of a novel 
parasite-specific RXR antagonist remains a preferable solution.

A number of nematode viability assays exist [21]. This study used a novel technique for measuring nematode vitality. An Andor camera was employed to video parasite movement over a 10-20 s period, and Matlab software was used to calculate the change in pixels resulting from worm movement. Overall, this method gave results consistent with the other viability assays, but provided several advantages over other methods. This assay was completely objective and did not require blinding. Results were reproducible between replicates and the speed of this system advocates its use for high-throughput screening of test compounds to determine their anthelmintic capacity. However, the camera motility assay also revealed effects on T. muris after incubation with the RXR agonist. Thus, this highlights the necessity of carrying out multiple assays when testing drug effects on parasite vitality. The techniques used here in showing an RXR antagonist to be a candidate anthelmintic lead compound may gain further traction as the T. muris genome [15] highlights additional, druggable targets to pursue.

\section{Conclusion}

In conclusion, RXR antagonism may be a useful novel method for treating trichuriasis, by reducing worm vitality at different lifecycle stages. This study also showed, that the T. muris genome has an RXR-like sequence, which may open new doors in the understanding of Trichuris biology.

\section{Competing interests}

The authors declare that they have no competing interests.

\section{Authors' contributions}

RJMH assisted with the design of the experiments, carried out vitality assays and immunohistochemistry and drafted the manuscript. TH and AG carried out the vitality assays. FP provided expertise on the camera analysis, carried out bioinformatic analysis and contributed to the drafting of the manuscript. TB carried out the bioinformatics analysis and assisted with drafting the manuscript. DS provided expertise on the camera analysis and helped with revision of the manuscript. KJE conceived and designed the experiment, and revised the manuscript. All authors read and approved the final manuscript.

\section{Acknowledgements}

The authors would like to acknowledge Hiroyuki Kagechika (Tokyo Medical and Dental University, Japan) for providing the HX630 and HX531 compounds. Also, we acknowledge with thanks the support of The Wellcome Trust in funding this work (Wellcome Trust Grant No: 091815).

\section{Author details}

${ }^{1}$ Faculty of Life Sciences, University of Manchester, AV Hill Building, Oxford Road, Manchester M13 9PT, UK. Wolfson Institute for Biomedical Research, Division of Medicine, University College London, Cruciform Building, Gower Street, London WC1E 6BT, UK.

Received: 21 February 2014 Accepted: 17 September 2014 Published: 27 September 2014
References

1. Pullan RL, Smith JL, Jasrasaria R, Brooker SJ: Global numbers of infection and disease burden of soil transmitted helminth infections in 2010. Parasites and Vectors 2014, 7:37.

2. Khuroo MS, Khuroo MS, Khuroo NS: Trichuris dysentery syndrome: a common cause of chronic iron deficiency anemia in adults in an endemic area (with videos). Gastrointest Endosc 2010, 71(1):200-204.

3. Geerts $S$, Gryseels B: Drug resistance in human helminths: current situation and lessons from livestock. Clin Microbiol Rev 2000, 13(2):207-222.

4. Mangelsdorf DJ, Borgmeyer U, Heyman RA, Zhou JY, Ong ES, Oro AE, Kakizuka A, Evans RM: Characterization of three RXR genes that mediate the action of 9-cis retinoic acid. Genes Dev 1992, 6(3):329-344.

5. Kastner P, Grondona JM, Mark M, Gansmuller A, LeMeur M, Decimo D, Vonesch J-L, Dollé P, Chambon P: Genetic analysis of RXRa developmental function: convergence of RXR and RAR signaling pathways in heart and eye morphogenesis. Cell 1994, 78(6):987-1003.

6. Altucci L, Leibowitz MD, Ogilvie KM, de Lera AR, Gronemeyer $\mathrm{H}$ : RAR and RXR modulation in cancer and metabolic disease. Nat Rev Drug Discov 2007, 6(10):793-810.

7. Heyman RA, Mangelsdorf DJ, Dyck JA, Stein RB, Eichele G, Evans RM, Thaller C 9-cis retinoic acid is a high affinity ligand for the retinoid $\mathrm{X}$ receptor. Cell 1992, 68(2):397-406.

8. Mangelsdorf DJ, Evans RM: The RXR heterodimers and orphan receptors. Cell 1995, 83(6):841-850.

9. Owen Gl, Zelent A: Origins and evolutionary diversification of the nuclear receptor superfamily. Cellular and molecular life sciences: CMLS 2000, 57(5):809-827.

10. Fantappie MR, Freebern WJ, Osman A, LaDuca J, Niles EG, LoVerde PT: Evaluation of Schistosoma mansoni retinoid $X$ receptor (SmRXR1 and SmRXR2) activity and tissue distribution. Mol Biochem Parasitol 2001, 115(1):87-99.

11. Kennedy MW, Garside LH, Goodrick LE, McDermott L, Brass A, Price NC, Kelly SM, Cooper A, Bradley JE: The Ov20 protein of the parasitic nematode Onchocerca volvulus. A structurally novel class of small helix-rich retinol-binding proteins. J Biol Chem 1997, 272(47):29442-29448.

12. Kennedy MW, Brass A, McCruden AB, Price NC, Kelly SM, Cooper A: The ABA-1 allergen of the parasitic nematode Ascaris suum: fatty acid and retinoid binding function and structural characterization. Biochemistry 1995, 34(20):6700-6710.

13. Wolff KM, Scott AL: Brugia malayi: retinoic acid uptake and localization. Exp Parasitol 1995, 80(2):282-290.

14. Hurst RJ, Else KJ: Trichuris muris research revisited: a journey through time. Parasitology 2013, 140(11):1325-1339.

15. Foth BJ, Tsai IJ, Reid AJ, Bancroft AJ, Nichol S, Tracey A, Holroyd N, Cotton JA, Stanley EJ, Zarowiecki M, Liu JZ, Huckvale T, Cooper PJ, Grencis RK, Berriman M: Whipworm genome and dual-species transcriptome analyses provide molecular insights into an intimate host-parasite interaction. Nat Genet 2014, 46(7):693-700.

16. Umemiya H, Fukasawa H, Ebisawa M, Eyrolles L, Kawachi E, Eisenmann G, Gronemeyer H, Hashimoto Y, Shudo K, Kagechika H: Regulation of retinoidal actions by diazepinylbenzoic acids. Retinoid synergists which activate the RXR-RAR heterodimers. J Med Chem 1997, 40(26):4222-4234.

17. Umemiya $H$, Kagechika H, Fukasawa $H$, Kawachi E, Ebisawa M, Hashimoto $Y$, Eisenmann G, Erb C, Pornon A, Chambon P, Gronemeyer H, Shudo K: Action mechanism of retinoid-synergistic dibenzodiazepines. Biochem Biophys Res Commun 1997, 233(1):121-125.

18. Kagechika $\mathrm{H}$ : Novel synthetic retinoids and separation of the pleiotropic retinoidal activities. Curr Med Chem 2002, 9(5):591-608.

19. Yamauchi T, Waki H, Kamon J, Murakami K, Motojima K, Komeda K, Miki H, Kubota N, Terauchi Y, Tsuchida A, Tsuboyama-Kasaoka N, Yamauchi N, Ide T, Hori W, Kato S, Fukayama M, Akanuma Y, Ezaki O, Itai A, Nagai R, Kimura S, Tobe K, Kagechika H, Shudo K, Kadowaki T: Inhibition of RXR and PPARgamma ameliorates diet-induced obesity and type 2 diabetes. J Clin Invest 2001, 108(7):1001-1013.

20. Wakelin D: Acquired immunity to Trichuris muris in the albino laboratory mouse. Parasitology 1967, 57(3):515-524

21. Silbereisen A, Tritten L, Keiser J: Exploration of novel in vitro assays to study drugs against Trichuris spp. J Microbiol Methods 2011, 87(2):169-175.

22. Shea C, Hough D, Xiao J, Tzertzinis G, Maina CV: An rxr/usp homolog from the parasitic nematode, Dirofilaria immitis. Gene 2004, 324:171-182. 
23. Hsieh JC, Jurutka PW, Selznick SH, Reeder MC, Haussler CA, Whitfield GK, Haussler MR: The T-box near the zinc fingers of the human vitamin D receptor is required for heterodimeric DNA binding and transactivation. Biochem Biophys Res Commun 1995, 215(1):1-7.

24. Bourguet W, Vivat V, Wurtz JM, Chambon P, Gronemeyer H, Moras D: Crystal structure of a heterodimeric complex of RAR and RXR ligandbinding domains. Mol Cell 2000, 5(2):289-298.

25. Lok JB, Morris RA, Sani BP, Shealy YF, Donnelly JJ: Synthetic and naturally occurring retinoids inhibit third- to fourth-stage larval development by Onchocerca lienalis in vitro. Tropical medicine and parasitology: official organ of Deutsche Tropenmedizinische Gesellschaft and of Deutsche Gesellschaft fur Technische Zusammenarbeit 1990, 41(2):169-173.

26. Zahner H, Sani BP, Shealy YF, Nitschmann A: Antifilarial activities of synthetic and natural retinoids in vitro. Tropical medicine and parasitology : official organ of Deutsche Tropenmedizinische Gesellschaft and of Deutsche Gesellschaft fur Technische Zusammenarbeit 1989, 40(3):322-326.

27. Philip S, Castro LF, da Fonseca RR, Reis-Henriques MA, Vasconcelos V, Santos MM, Antunes A: Adaptive evolution of the Retinoid X receptor in vertebrates. Genomics 2012, 99(2):81-89.

28. Freebern WJ, Niles EG, LoVerde PT: RXR-2, a member of the retinoid $x$ receptor family in Schistosoma mansoni. Gene 1999, 233(1-2):33-38.

29. Cliffe $L$, Grencis RK: The Trichuris muris system: a paradigm of resistance and susceptibility to intestinal nematode infection. Adv Parasitol 2004, 57:255-307.

30. Huttemann M, Schmahl G, Mehlhorn H: Light and electron microscopic studies on two nematodes, Angiostrongylus cantonensis and Trichuris muris, differing in their mode of nutrition. Parasitol Res 2007, 101(Suppl 2):S225-232

31. Long KZ, Estrada-Garcia T, Rosado JL, Ignacio Santos J, Haas M, Firestone M, Bhagwat J, Young C, DuPont HL, Hertzmark E, Nanthakumar NN: The effect of vitamin A supplementation on the intestinal immune response in Mexican children is modified by pathogen infections and diarrhea. J Nutr 2006, 136(5):1365-1370.

32. Hurst RJ, De Caul A, Little MC, Kagechika H, Else KJ: The retinoic acid receptor agonist Am80 increases mucosal inflammation in an IL-6 dependent manner during Trichuris muris infection. J Clin Immunol 2013, 33(8):1386-1394

33. Spencer SP, Wilhelm C, Yang Q, Hall JA, Bouladoux N, Boyd A, Nutman TB, Urban JF Jr, Wang J, Ramalingam TR, Bhandoola A, Wynn TA, Belkaid Y: Adaptation of innate lymphoid cells to a micronutrient deficiency promotes type 2 barrier immunity. Science 2014, 343(6169):432-437.

34. Morishita K, Yakushiji N, Ohsawa F, Takamatsu K, Matsuura N, Makishima M, Kawahata M, Yamaguchi K, Tai A, Sasaki K, Kakuta H: Replacing alkyl sulfonamide with aromatic sulfonamide in sulfonamide-type RXR agonists favors switch towards antagonist activity. Bioorg Med Chem Lett 2009, 19(3):1001-1003.

35. Martin RJ: Modes of action of anthelmintic drugs. Veterinary journal 1997, 154(1):11-34

36. Jin L, Feng X, Rong H, Pan Z, Inaba Y, Qiu L, Zheng W, Lin S, Wang R, Wang Z, Liu H, Li S, Xie W, Li Y: The antiparasitic drug ivermectin is a novel FXR ligand that regulates metabolism. Nat Commun 2013, 4:1937.

37. Cully DF, Vassilatis DK, Liu KK, Paress PS, Van der Ploeg LH, Schaeffer JM, Arena JP: Cloning of an avermectin-sensitive glutamate-gated chloride channel from Caenorhabditis elegans. Nature 1994, 371(6499):707-711.

doi:10.1186/1471-2334-14-520

Cite this article as: Hurst et al:: An antagonist of the retinoid $\mathrm{X}$ receptor reduces the viability of Trichuris muris in vitro. BMC Infectious Diseases 2014 14:520.

\section{Submit your next manuscript to BioMed Central and take full advantage of:}

- Convenient online submission

- Thorough peer review

- No space constraints or color figure charges

- Immediate publication on acceptance

- Inclusion in PubMed, CAS, Scopus and Google Scholar

- Research which is freely available for redistribution 